\title{
Reductive Coupling Reaction of Benzyl, Allyl and Alkyl Halides in Aqueous Medium Promoted by Zinc
}

\author{
Ana C. P. F. de Sá, Giovanna M. A. Pontes, José A. L. dos Anjos, Sidney R. Santana, \\ Lothar W. Bieber and Ivani Malvestiti*
}

\author{
Departamento de Química Fundamental, Universidade Federal de Pernambuco, Cidade Universitária, \\ 50670-901 Recife - PE, Brazil
}

\begin{abstract}
Haletos orgânicos sofrem dimerização redutiva (acoplamento tipo Wurtz) promovida por zinco a temperatura ambiente em meio aquoso. Essas reações são catalisadas por sais de cobre. Este procedimento descreve um método simples e eficiente para o homoacoplamento de brometos benzílicos e alílicos e de iodetos de alquila primários.
\end{abstract}

Organic halides undergo reductive dimerization (Wurtz-type coupling) promoted by zinc at room temperature in aqueous medium. The reaction yields are strongly enhanced by copper catalysis. This coupling procedure provides an efficient and simple method for the homocoupling of benzylic and allylic bromides and primary alkyl iodides.

Keywords: homocoupling reaction, organic halides, aqueous media

\section{Introduction}

The reductive coupling of organic halides is an important method for the formation of carbon-carbon bonds where Wurtz $^{1}$ and Ullmann ${ }^{2}$ reactions are classical methods for the synthesis of bialkyl and biaryl compounds. The synthesis of biaryls is usually accomplished by dimerization of aryl halides catalyzed by nickel or palladium complexes in the presence of a reducing agent such as zinc powder ${ }^{3}$ or upon electrochemical reduction. The homocoupling of several organic halides has been performed in good yields under anhydrous conditions, in some cases using activated metals, ${ }^{4}$ and the interest for these reactions has increased. ${ }^{5-10}$ Advances in metal promoted Barbier-type additions to carbonyl compounds in aqueous media ${ }^{11}$ led to the expectation that a Wurtz-type coupling could also be performed in water.

$$
\mathrm{R}-\mathrm{X} \underset{\text { Catalyst }}{\stackrel{\text { Metal } / \mathrm{H}_{2} \mathrm{O}}{\longrightarrow}} \mathrm{R}-\mathrm{R}+\mathrm{R}-\mathrm{H}
$$

Indeed, a long time ago, Nosek ${ }^{12}$ described the dimerization of benzyl and n-alkyl halides promoted by zinc/silver in water under reflux with yields up to $70 \%$.

*e-mail: ivani@ufpe.br
Chan ${ }^{9}$ obtained a similar coupling promoted by $\mathrm{Mn} / \mathrm{CuCl}_{2}$ in water under argon atmosphere at room temperature with yields ranging from 52 to $87 \%$. $\mathrm{Li}$ and $\mathrm{Chan}^{13}$ also mentioned the dimerization of 2-(chloromethyl)-3-iodo1-propene under aqueous conditions in the presence of zinc, but no experimental conditions were given. More recently, Sasson ${ }^{14}$ reported the palladium-catalyzed coupling of haloaryl compounds in water in the presence of zinc.

\section{Results and Discussion}

Our interest in the aqueous Wurtz-type coupling was originated from the observation that high amount of bibenzyl was produced when the Barbier addition of benzyl bromide to benzaldehyde was performed with zinc in aqueous ammonium chloride. ${ }^{15}$ In this paper we report the improvement of this dimerization and its extension to other organic halides. The influence of the reaction medium was investigated systematically for benzyl bromide (Table 1).

No decisive influence of the $\mathrm{pH}$ could be observed: in pure water $29 \%$ of the dimer was produced, and both acid and basic conditions gave lower dimerisation yields (entries 1-3). The use of concentrated salt solutions such as calcium chloride (entry 4) gave no significant improvement, except for ammonium chloride, which led to comparable amounts of coupling and reduction products 
Table 1. Aqueous reductive coupling of organic halides: the effect of the catalyst ${ }^{a}$

\begin{tabular}{|c|c|c|c|c|c|}
\hline Entry & $\mathrm{R}-\mathrm{X}$ & Solution & Catalyst & $\begin{array}{l}\text { Yielc } \\
\text { R-R }\end{array}$ & $\mathrm{R}-\mathrm{H}$ \\
\hline 1 & $\mathrm{C}_{6} \mathrm{H}_{5} \mathrm{CH}_{2} \mathrm{Br}$ & $\mathrm{H}_{2} \mathrm{O}$ & - & 29 & 71 \\
\hline 2 & $\mathrm{C}_{6} \mathrm{H}_{5} \mathrm{CH}_{2} \mathrm{Br}$ & $\mathrm{HCl}\left(1 \mathrm{~mol} \mathrm{~L}^{-1}\right)$ & - & 17 & 62 \\
\hline 3 & $\mathrm{C}_{6}^{0} \mathrm{H}_{5} \mathrm{CH}_{2} \mathrm{Br}$ & $\mathrm{K}_{2} \mathrm{HPO}_{4}{ }^{\mathrm{b}}$ & - & 17 & 58 \\
\hline 4 & $\mathrm{C}_{6} \mathrm{H}_{5} \mathrm{CH}_{2} \mathrm{Br}$ & $\mathrm{CaCl}_{2}{ }^{\mathrm{c}}$ & - & 28 & 68 \\
\hline 5 & $\mathrm{C}_{6} \mathrm{H}_{5} \mathrm{CH}_{2} \mathrm{Br}$ & $\mathrm{NH}_{4} \mathrm{Cl}^{\mathrm{c}}$ & - & 48 & 50 \\
\hline 6 & $\mathrm{C}_{6} \mathrm{H}_{5} \mathrm{CH}_{2}^{2} \mathrm{Br}$ & $\mathrm{NH}_{4}^{4} \mathrm{Cl}^{\mathrm{c}}$ & $\mathrm{AgNO}_{3}$ & 58 & 25 \\
\hline 7 & $\mathrm{C}_{6} \mathrm{H}_{5} \mathrm{CH}_{2} \mathrm{Br}$ & $\mathrm{NH}_{4} \mathrm{Cl}^{\mathrm{c}}$ & $\mathrm{CuCl}_{2}{ }^{3}$ & 91 & 8 \\
\hline 8 & $\mathrm{C}_{6} \mathrm{H}_{5} \mathrm{CH}_{2} \mathrm{Cl}$ & $\mathrm{NH}_{4}^{4} \mathrm{Cl}^{\mathrm{c}}$ & $\mathrm{CuCl}_{2}^{2}$ & 63 & 34 \\
\hline 9 & $4-\mathrm{CH}_{3}^{3} \mathrm{OC}_{6}^{2} \mathrm{H}_{4} \mathrm{CH}_{2} \mathrm{Cl}{ }^{\mathrm{d}}$ & $\mathrm{NH}_{4}^{4} \mathrm{Cl}^{\mathrm{c}}$ & $\mathrm{CuCl}_{2}^{2}$ & 24 & 42 \\
\hline 10 & $4-\mathrm{FC}_{6}^{3} \mathrm{H}_{4} \mathrm{CH}_{2}^{4} \mathrm{Cl}^{2}$ & $\mathrm{NH}_{4}^{4} \mathrm{Cl}^{\mathrm{c}}$ & $\mathrm{CuCl}_{2}^{2}$ & 68 & 30 \\
\hline 11 & $4-\mathrm{FC}_{6} \mathrm{H}_{4} \mathrm{CH}_{2} \mathrm{Br}$ & $\mathrm{NH}_{4} \mathrm{Cl}^{\mathrm{c}}$ & $\mathrm{CuCl}_{2}$ & 75 & 23 \\
\hline 12 & $\mathrm{C}_{6} \mathrm{H}_{5} \mathrm{C} \mathrm{H}_{(}\left(\mathrm{CH}_{3}\right) \mathrm{Br}^{\mathrm{e}}$ & $\mathrm{NH}_{4}^{4} \mathrm{Cl}^{\mathrm{c}}$ & $\mathrm{CuCl}_{2}$ & 80 & 13 \\
\hline 13 & $\mathrm{C}_{6}^{6} \mathrm{H}_{5}^{3} \mathrm{C}\left(\mathrm{CH}_{3}\right)_{2} \mathrm{Cl}$ & $\mathrm{NH}_{4}^{4} \mathrm{Cl}^{\mathrm{c}}$ & $\mathrm{CuCl}_{2}^{2}$ & 58 & 31 \\
\hline 14 & $1-\mathrm{ClCH}_{2} \mathrm{C}_{10} \mathrm{H}_{7}$ & $\mathrm{NH}_{4}^{4} \mathrm{Cl}^{\mathrm{c}}$ & $\mathrm{CuCl}_{2}^{2}$ & 56 & 19 \\
\hline 15 & $2-\mathrm{BrCH}_{2} \mathrm{C}_{10} \mathrm{H}_{7}{ }^{\mathrm{f}}$ & $\mathrm{NH}_{4}^{4} \mathrm{Cl}^{\mathrm{c}}$ & $\mathrm{CuCl}_{2}^{2}$ & 26 & 14 \\
\hline 16 & $\mathrm{CH}_{2}=\mathrm{CHCH}_{2} \mathrm{Br}$ & $\mathrm{NH}_{4}^{4} \mathrm{Cl}^{\mathrm{c}}$ & $\mathrm{CuCl}_{2}^{2}$ & 13 & $\mathrm{~g}$ \\
\hline 17 & $\mathrm{CH}_{2}^{2}=\mathrm{CHCH}_{2}^{2} \mathrm{I}$ & $\mathrm{NH}_{4}^{4} \mathrm{Cl}^{\mathrm{c}}$ & $\mathrm{CuCl}_{2}^{2}$ & 24 & $\mathrm{~g}$ \\
\hline 18 & $\mathrm{CH}_{2}^{2}=\mathrm{C}\left(\mathrm{CH}_{3}\right)^{2} \mathrm{CH}_{2} \mathrm{Br}$ & $\mathrm{NH}_{4}^{4} \mathrm{Cl}^{\mathrm{c}}$ & $\mathrm{CuCl}_{2}^{2}$ & 30 & $\mathrm{~g}$ \\
\hline 19 & $\mathrm{CH}_{3}^{2} \mathrm{CH}=\mathrm{CHCH}_{2} \mathrm{Br}{ }^{\mathrm{h}}$ & $\mathrm{NH}_{4} \mathrm{Cl}^{\mathrm{c}}$ & $\mathrm{CuCl}_{2}^{2}$ & $59^{\mathrm{i}}$ & $\mathrm{g}$ \\
\hline 20 & $\left(\mathrm{CH}_{3}\right)_{2} \mathrm{C}=\mathrm{CHCH}_{2} \mathrm{Br}$ & $\mathrm{NH}_{4} \mathrm{Cl}^{\mathrm{c}}$ & $\mathrm{CuCl}_{2}^{2}$ & $61^{j}$ & $\mathrm{~g}$ \\
\hline 21 & $\mathrm{C}_{6} \mathrm{H}_{5} \mathrm{CH}=\mathrm{CHCH}_{2} \mathrm{Cl}$ & $\mathrm{NH}_{4}^{4} \mathrm{Cl}^{\mathrm{c}}$ & $\mathrm{CuCl}_{2}^{2}$ & $52^{\mathrm{k}}$ & $48^{1}$ \\
\hline 22 & $\mathrm{C}_{6} \mathrm{H}_{5} \mathrm{CH}=\mathrm{CHCH}_{2} \mathrm{Br}$ & $\mathrm{NH}_{4}^{4} \mathrm{Cl}^{\mathrm{c}}$ & $\mathrm{CuCl}_{2}^{2}$ & $87^{m}$ & $13^{n}$ \\
\hline
\end{tabular}

${ }^{a}$ Typical procedure: to $1.5 \mathrm{~mL}$ of vigorously stirred aqueous solution of the indicated composition, $10 \mathrm{mg}$ of catalyst and $1.0 \mathrm{mmol}$ of the organic halide were added followed by $1.5 \mathrm{mmol}$ of zinc dust over a period of 10 minutes. After $2 \mathrm{~h}$ of stirring, the mixture was hydrolysed with $2.0 \mathrm{~mL}$ of $2 \mathrm{~mol} \mathrm{~L}^{-1} \mathrm{HCl}$ and extracted with $1.0 \mathrm{~mL}$ of $\mathrm{CCl}_{4}$ containing cyclohexane or anisole as internal quantitative reference. The products were analysed by ${ }^{1} \mathrm{H}$ RMN and GC/MS. ${ }^{\mathrm{b}} 1.5 \mathrm{~g}$ of $\mathrm{K}_{2} \mathrm{HPO}_{4}$ in $2.0 \mathrm{~mL}$ of $\mathrm{H}_{2} \mathrm{O}$. ${ }^{\mathrm{c}}$ saturated salt solution. ${ }^{\mathrm{d}} 34 \%$ of starting material remained unchanged. ${ }^{\mathrm{e}} 1: 1$ Mixture of $\mathrm{dl}$ and meso. ${ }^{\mathrm{f}} 0.5 \mathrm{~mL}$ of $\mathrm{CH}_{2} \mathrm{Cl}_{2}$ was used as co-solvent, $35 \%$ of starting material remained unchanged. ${ }^{\mathrm{g}}$ Not determined. ${ }^{\mathrm{h}}$ The starting material contained $15 \%$ of the isomeric 3-bromobutene. ${ }^{\mathrm{i}}$ Mixture of 7 isomers in the ratio of 7:8:32:8:29:14:2 (GC). The overall ratio of a:g coupling determined by ${ }^{1} \mathrm{H}-\mathrm{NMR}$ was 59:41. ${ }^{\mathrm{j}} \alpha / \alpha, \gamma / \gamma$ and $\alpha / \gamma$ coupling in the ratio of $68: 25: 7$ (GC). ${ }^{\mathrm{k}} \alpha / \alpha, \alpha / \gamma$ and $\gamma / \gamma$ coupling in the ratio of 49:49:2 (GC). ${ }^{1}$ A 3:1 mixture of allylbenzene and $\beta$-methylstyrene was produced in $48 \%$ yield. ${ }^{\mathrm{m}} \alpha / \alpha, \alpha / \gamma$ and $\gamma / \gamma$ coupling in the ratio of $51: 42: 7 .{ }^{\mathrm{n}}$ A $2: 1$ mixture of allylbenzene and $\beta$-methylstyrene was produced in $13 \%$ yield.

(entry 5). In contrast to the aqueous Barbier addition of allylic, benzylic and propargylic halides to carbonyl compounds, ${ }^{11,15}$ water miscible co-solvents such as THF, dioxane, methanol, DMF or DMSO suppressed completely the coupling reaction of benzyl bromide, and only reduction of the halide was observed. Further improvement on the reactions carried out in concentrated $\mathrm{NH}_{4} \mathrm{Cl}$ solution was achieved by adding silver or copper salts as catalysts leading to dimerisation yields of 58 and $91 \%$, respectively (entries 6 and 7).

Based on these encouraging results other halides were examined under the conditions of experiment entry 7. Benzyl chloride led to the coupling product in lower yield (entry 8) and the introduction of the $p$-methoxy substituent into the phenyl ring led to a further decrease of the yield (entry 9), but 4-fluoro derivatives gave comparable yields to the unsubstituted aromatic ring (entries 10 and 11). Additional branching $\alpha$ to the halogen led to lower yields of the homocoupling product (entries 7, 8, 12 and 13). The coupling reaction of 1-(chloromethyl)naphthalene led to the coupling product in 56\% yield (entry 14). The poor yield observed using 2-(bromomethyl)naphthalene (entry 15) can be due to the use of a co-solvent to dissolve the starting halide. Allyl bromide and iodide led to 1,5hexadiene in $13 \%$ and $24 \%$, respectively (entries 16 and 17). In this case, the formation of propene was observed by ${ }^{1} \mathrm{H}$ NMR, but the yield was not determined. While methallyl bromide produced low amounts of dimer (entry 18), the crotyl, prenyl and cinnamyl bromide gave more satisfactory overall yields of a mixture of all possible isomers ${ }^{16}$ (entries $19-22$ ), but the $\alpha-\alpha$ coupling product was predominant in all cases.

In order to improve the yields of the homocoupling reaction of allyl bromide other conditions were explored (Table 2).

The presence of a co-solvent has shown to be critical for the success of this reaction with allyl bromide (entries 1-3,6 and 7). The use of miscible solvents such as dioxane gave poor yield of the coupling product (entry 6). However, non miscible co-solvents led to better yields and best conversions were obtained in benzene. The influence of the $\mathrm{pH}$ of the aqueous solution was also important: the use 
Table 2. Reductive coupling of allylic halides with zinc in aqueous media ${ }^{a}$

\begin{tabular}{|c|c|c|c|c|c|}
\hline Entry & Halide $(1.0 \mathrm{mmol})$ & Solution & Co-solvent & Metal / Catalyst & Reductive coupling (\%) \\
\hline 1 & $\mathrm{CH}_{2}=\mathrm{CHCH}_{2} \mathrm{Br}$ & $\mathrm{K}_{2} \mathrm{HPO}_{4}(\mathrm{pH} 12)$ & - & $\mathrm{Zn} / \mathrm{CuI}$ & 0 \\
\hline 2 & $\mathrm{CH}_{2}=\mathrm{CHCH}_{2} \mathrm{Br}$ & $\mathrm{K}_{2} \mathrm{HPO}_{4}(\mathrm{pH} 12)$ & $\mathrm{C}_{6} \mathrm{H}_{6}$ & $\mathrm{Zn}$ & 6 \\
\hline 3 & $\mathrm{CH}_{2}=\mathrm{CHCH}_{2} \mathrm{Br}$ & $\mathrm{K}_{2} \mathrm{HPO}_{4}(\mathrm{pH} 12)$ & $\mathrm{C}_{6} \mathrm{H}_{6}$ & $\mathrm{Zn} / \mathrm{CuI}$ & 69 \\
\hline 4 & $\mathrm{CH}_{2}^{2}=\mathrm{CHCH}_{2}^{2} \mathrm{Br}$ & $\mathrm{K}_{2}^{2} \mathrm{HPO}_{4}(\mathrm{pH} 12)$ & $\mathrm{C}_{6}^{0} \mathrm{H}_{6}^{0}$ & $\mathrm{Zn} / \mathrm{Cu}^{\mathrm{b}}$ & 25 \\
\hline 5 & $\mathrm{CH}_{2}=\mathrm{CHCH}_{2} \mathrm{Br}$ & $\mathrm{K}_{2} \mathrm{HPO}_{4}(\mathrm{pH} 12)$ & $\mathrm{C}_{6} \mathrm{H}_{6}$ & $\mathrm{Zn} / \mathrm{CuCl}_{2}$ & 10 \\
\hline 6 & $\mathrm{CH}_{2}=\mathrm{CHCH}_{2} \mathrm{Br}$ & $\mathrm{K}_{2} \mathrm{HPO}_{4}(\mathrm{pH} 12)$ & dioxane & $\mathrm{Zn} / \mathrm{CuI}$ & 13 \\
\hline 7 & $\mathrm{CH}_{2}^{2}=\mathrm{CHCH}_{2}^{2} \mathrm{Br}$ & $\mathrm{K}_{2}^{2} \mathrm{HPO}_{4}(\mathrm{pH} 12)$ & $\mathrm{C}_{6} \mathrm{H}_{12}$ & $\mathrm{Zn} / \mathrm{CuI}$ & 58 \\
\hline 8 & $\mathrm{CH}_{2}^{2}=\mathrm{CHCH}_{2}^{2} \mathrm{Br}$ & $\mathrm{K}_{2}^{2} \mathrm{HPO}_{4} / \mathrm{Na}_{2} \mathrm{HPO}_{4}(\mathrm{pH} 5)$ & $\mathrm{C}_{6}^{6} \mathrm{H}_{6}$ & $\mathrm{Zn} / \mathrm{CuI}$ & 7 \\
\hline 9 & $\mathrm{CH}_{2}^{2}=\mathrm{CHCH}_{2} \mathrm{Br}$ & $\mathrm{K}_{2}^{2} \mathrm{HPO}_{4} / \mathrm{Na}_{2} \mathrm{HPO}_{4}(\mathrm{pH} 7)$ & $\mathrm{C}_{6} \mathrm{H}_{6}$ & $\mathrm{Zn} / \mathrm{CuI}$ & 23 \\
\hline 10 & $\mathrm{CH}_{2}^{2}=\mathrm{CHCH}_{2}^{2} \mathrm{Br}$ & $\mathrm{K}_{3}^{2} \mathrm{PO}_{4}(\mathrm{pH} 13)$ & $\mathrm{C}_{6}^{6} \mathrm{H}_{6}^{6}$ & $\mathrm{Zn} / \mathrm{CuI}$ & 32 \\
\hline 11 & $\mathrm{CH}_{2}^{2}=\mathrm{CHCH}_{2}^{2} \mathrm{Br}$ & $\mathrm{KOH}^{3}(\mathrm{pH} 14)$ & $\mathrm{C}_{6}^{6} \mathrm{H}_{6}^{6}$ & $\mathrm{Zn} / \mathrm{CuI}$ & 25 \\
\hline 12 & $\mathrm{CH}_{2}=\mathrm{CHCH}_{2} \mathrm{Br}$ & $\mathrm{KOH}(\mathrm{pH} 14)$ & $\mathrm{C}_{6} \mathrm{H}_{6}$ & $\mathrm{Zn} / \mathrm{Ag}$ & 12 \\
\hline 13 & $\mathrm{CH}_{2}=\mathrm{CHCH}_{2} \mathrm{Br}$ & $\mathrm{K}_{2} \mathrm{HPO}_{4}(\mathrm{pH} 12)$ & $\mathrm{C}_{6} \mathrm{H}_{6}^{0}$ & $\mathrm{Zn} / \mathrm{Ag}$ & 58 \\
\hline 14 & $\mathrm{CH}_{2}=\mathrm{CHCH}_{2} \mathrm{Br}$ & $\mathrm{K}_{2} \mathrm{HPO}_{4}(\mathrm{pH} 12)$ & $\mathrm{C}_{6} \mathrm{H}_{6}$ & $\mathrm{Zn} / \mathrm{Ag} / \mathrm{galvinoxyl}$ & 37 \\
\hline 15 & $\mathrm{CH}_{2}^{2}=\mathrm{CHCH}_{2}^{2} \mathrm{Cl}$ & $\mathrm{K}_{2}^{2} \mathrm{HPO}_{4}(\mathrm{pH} 12)$ & $\mathrm{C}_{6}^{6} \mathrm{H}_{6}^{6}$ & $\mathrm{Zn} / \mathrm{CuI}$ & 7 \\
\hline
\end{tabular}

a Typical procedure: a mixture of $1.5 \mathrm{~mL}$ of a concentrated aqueous solution of the indicated composition, $0.5 \mathrm{~mL}$ of co-solvent, catalyst $\left(\mathrm{CuCl}{ }_{2}\right.$ $10 \mathrm{mg}$ or $\mathrm{CuI} 0.5 \mathrm{mmol})$ and the organic halide $(1.0 \mathrm{mmol})$ was stirred at $30{ }^{\circ} \mathrm{C} . \mathrm{Zn}$ or $\mathrm{Zn} / \mathrm{Ag}(1 \%)$ was added to the mixture at once. After $2 \mathrm{~h}$, the mixture was hydrolysed with $2 \mathrm{~mol} \mathrm{~L}^{-1} \mathrm{HCl}$ and extracted as described before. ${ }^{\mathrm{b}} 0.5 \mathrm{mmol}$ of $\mathrm{Cu}$ was prepared by reduction of $\mathrm{CuCl}_{2}$ by $\mathrm{Zn}$, then the allyl halide was added to the mixture followed by addition of $2.0 \mathrm{mmol}$ of $\mathrm{Zn}$.

of basic solutions increased remarkably the yields from $13 \%$ in $\mathrm{NH}_{4} \mathrm{Cl}$ solution (Table 1 , entry 16 ) to $23 \%$ in $\mathrm{K}_{2} \mathrm{HPO}_{4} / \mathrm{Na}_{2} \mathrm{HPO}_{4}(\mathrm{pH} 7)$ and finally to $69 \%$ in $\mathrm{K}_{2} \mathrm{HPO}_{4}$ solution ( $\mathrm{pH}$ 12) (Table 2, entries 9 and 3). However, for $\mathrm{pH}$ higher than 12 a deleterious effect on the yield was observed (entries 10, 11 and 12).

In order to get better yields of the coupling product, several transition metal salts were employed as catalysts and best results were achieved in $\mathrm{Zn} / \mathrm{Ag}(1 \%)$ and $\mathrm{Zn} / \mathrm{CuI}$, yielding 1,5 -hexadiene in $58 \%$ and $69 \%$, respectively (entries 13 and 3). The study of the homocoupling reaction of the benzylic and allylic halides led us to the development of three experimental procedures: method A (aqueous saturated $\mathrm{NH}_{4} \mathrm{Cl}$ solution, $\mathrm{Zn}, \mathrm{CuCl}_{2}$ ); method $\mathrm{B}$ (aqueous $\mathrm{K}_{2} \mathrm{HPO}_{4}$ solution, $\mathrm{C}_{6} \mathrm{H}_{6}, \mathrm{Zn}, \mathrm{CuI}$ ) and method $\mathrm{C}$ (aqueous $\mathrm{KOH}$ solution, $\mathrm{C}_{6} \mathrm{H}_{6}, \mathrm{Zn} / \mathrm{Ag}[1 \%]$ ). It was observed that the best reaction conditions depended upon the halide structure (Table 3).

As pointed out in Table 3, method A was most suitable for benzylic halides (entries 1 and 2), but also interesting for some substituted allyl bromides and primary alkyl halides (Table 3, entries 5, 6, 10). Method B is better for

Table 3. Comparative methods for aqueous reductive coupling of organic halides

\begin{tabular}{|c|c|c|c|c|}
\hline Entry & Halide & $\begin{array}{l}\text { Yields for Method A } \\
\left(\mathrm{NH}_{4} \mathrm{Cl} / \mathrm{Zn} / \mathrm{CuCl}_{2}\right)\end{array}$ & $\begin{array}{l}\text { Yields for Method B a } \\
\left(\mathrm{K}_{2} \mathrm{HPO}_{4} / \mathrm{C}_{6} \mathrm{H}_{6} / \mathrm{Zn} / \mathrm{CuI}\right)\end{array}$ & $\begin{array}{l}\text { Yields for Method } \mathrm{C}^{a} \\
\left(\mathrm{KOH} / \mathrm{C}_{6} \mathrm{H}_{6} / \mathrm{Zn}-\mathrm{Ag}\right)\end{array}$ \\
\hline 1 & $\mathrm{PhCH}_{2} \mathrm{Br}$ & 91 & 52 & 24 \\
\hline 2 & $\mathrm{PhCH}_{2} \mathrm{Cl}$ & 63 & 48 & 3 \\
\hline 3 & $\mathrm{CH}_{2}=\mathrm{CHCH}_{2} \mathrm{Br}$ & 13 & 69 & 12 \\
\hline 4 & $\mathrm{CH}_{2}=\mathrm{C}\left(\mathrm{CH}_{3}\right) \mathrm{CH}_{2} \mathrm{Br}$ & 30 & 72 & 52 \\
\hline 5 & $\mathrm{CH}_{3} \mathrm{CH}_{2}=\mathrm{CHCH}_{2} \mathrm{Br}^{\mathrm{b}}$ & $59(\alpha: \gamma=59: 41)$ & $59(\alpha: \gamma=61: 39)$ & $55(\alpha: \gamma=64: 36)$ \\
\hline 6 & $\left(\mathrm{CH}_{3}\right)_{2} \mathrm{C}=\mathrm{CHCH}_{2} \mathrm{Br}$ & $61(\alpha: \gamma=72: 28)$ & $90(\alpha: \gamma=71: 29)$ & $67(\alpha: \gamma=72: 28)$ \\
\hline 7 & $\mathrm{CH}_{3} \mathrm{C}^{\circ} \mathrm{CCH}_{2} \mathrm{Br}$ & $33(\alpha: \gamma=73: 27)$ & $66(\alpha: \gamma=88: 12)$ & $20^{c}$ \\
\hline 8 & $\mathrm{PhCH}_{2} \mathrm{CH}_{2} \mathrm{I}^{2}$ & - & 47 & 40 \\
\hline 9 & $\mathrm{CH}_{3} \mathrm{CH}_{2} \mathrm{CH}_{2} \mathrm{CH}_{2} \mathrm{I}$ & 36 & 51 & 49 \\
\hline 10 & $\left(\mathrm{CH}_{3}\right)_{2} \mathrm{CHCH}_{2} \mathrm{I}$ & 52 & 52 & 52 \\
\hline 11 & $\left(\mathrm{CH}_{3}\right)_{3} \mathrm{CCH}_{2} \mathrm{I}^{2}$ & 18 & 69 & 7 \\
\hline 12 & $\left(\mathrm{CH}_{3}\right)_{2} \mathrm{CHI}$ & - & 29 & 37 \\
\hline 13 & $\mathrm{CH}_{3} \mathrm{CH}_{2} \mathrm{CHI}\left(\mathrm{CH}_{3}\right)$ & 9 & 25 & 37 \\
\hline 14 & cyclo- $\mathrm{C}_{6} \mathrm{H}_{11} \mathrm{I}$ & 7 & 62 & 52 \\
\hline 15 & $\left(\mathrm{CH}_{3}\right)_{3} \mathrm{CI}$ & 0,9 & 6 & 10 \\
\hline 16 & $\mathrm{ICH}_{2} \mathrm{CH}_{2} \mathrm{CH}_{2} \mathrm{CH}_{2} \mathrm{I}$ & $0: 61^{\mathrm{d}}$ & $0: 48^{\mathrm{d}}$ & $6: 47^{\mathrm{d}}$ \\
\hline 17 & $\mathrm{ICH}_{2}\left(\mathrm{CH}_{2}\right)_{4} \mathrm{CH}_{2} \mathrm{I}$ & $0: 72^{\mathrm{d}}$ & $1: 13^{\mathrm{d}}$ & $3: 40^{\mathrm{d}}$ \\
\hline
\end{tabular}

a $0.5 \mathrm{~mL}$ of benzene was used as co-solvent ${ }^{\mathrm{b}}$ The starting material contained $15 \%$ of the isomeric 3-bromobutene. ${ }^{\mathrm{c}}$ Only the $\alpha / \alpha$ coupling was observed. ${ }^{\mathrm{d}}$ Ratio of intermolecular coupling : oligomerisation. 
allyl and butynyl bromides (entries 3-7) and for primary alkyl iodides (entries 8-11); secondary alkyl iodides also could be dimerized in up to $62 \%$ yield (entries 12-14). Comparable or slightly better results with these substrates were achieved using method $\mathrm{C}$, but t-butyl iodide gave a modest $10 \%$ yield of the dimer with this method (entry 15). All methods failed with n-butyl bromide. The attempt of an intramolecular coupling of diiodobutane and diiodohexane ${ }^{17}$ produced mainly intermolecular coupled oligomers and only trace amounts of cycloalkanes (entries 16 and 17).

In order to understand the mechanistic nature of this dimerization further experiments were performed. In contrast to the aqueous Reformatsky reaction, ${ }^{18}$ the presence of a radical initiator (benzoyl peroxide) and/or radical scavenger (galvinoxyl) produced no significant effects, although these results by themselves can not exclude either a radical mechanism or an $\mathrm{S}_{\mathrm{N}} 2$ reaction.

The data obtained with neopentyl iodide, $69 \%$ of the dimer (entry 11), are in agreement with radical results reported by Garst, ${ }^{19}$ even though the yields observed for the primary, secondary and tertiary halides (entries 9, $10,12,13$ and 15) could follow the order for an $\mathrm{S}_{\mathrm{N}} 2$ reaction. Mechanistic studies on the related intramolecular cyclization of optically active 1,3-dihaloalkanes (Hass process) in the presence of $\mathrm{Zn}, \mathrm{Cr}$ (II) or $\mathrm{Na}$ have shown racemization on one carbon and inversion on the other. ${ }^{20}$ This may suggest the formation of an organometallic intermediate via a radical process, which attacks a second halide with inversion.

The process under our conditions probably proceeds on the metal surface as supported by the complete suppression of the coupling reaction of benzylic halides in the presence of a miscible co-solvent, which should remove the halide from the metal surface allowing the approach of water to the hydrophobic metal or organometallic intermediate.

Further support for a radical intermediate was obtained from the homocoupling of the 6-iodo-1-hexene and iodomethylcyclopropane. Competing unimolecular radical reactions have been used to investigate radical reaction rates, in which cases information has been obtained from the product analysis. ${ }^{21,22}$ The cyclization of 5-hexenyl to cyclopentylmethyl radicals has been widely used as a mechanistic probe and kinetic standard, with a rate constant of $2.3 \times 10^{5} \mathrm{~s}^{-1}$ at $25^{\circ} \mathrm{C}$ well established since $1968 .{ }^{23}$ The literature also has shown that cyclopropylmethyl radicals undergo a very rapid ring opening, with a rate constant of $1.3 \times 10^{8} \mathrm{~s}^{-1}$ at $25^{\circ} \mathrm{C} . .^{21}$

The homocoupling reaction of 6-iodo-1-hexene was tested, using methods $\mathrm{A}$ and $\mathrm{C}$, and in both cases mixtures of 1,11-dodecadiene (1), 7-cyclopentyl-1-heptene (2) and 1,2-cyclopentylethane (3) (Figure 1) were observed (Table 4, entries 1 and 2). However, organometallic intermediates are also known to cyclize to give cyclopentanoid products, ${ }^{24}$ thus the above experiment is not conclusive.

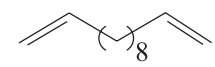

1

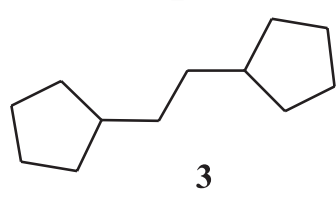

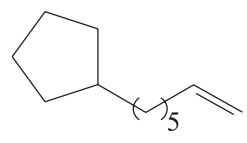

2

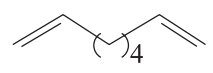

4
Figure 1. Products of the homocoupling reaction of 6-iodo-1-hexene and iodomethylcyclopropane.

The major product observed in saturated $\mathrm{NH}_{4} \mathrm{Cl}$ solution and in the presence of zinc/ $\mathrm{CuCl}_{2}(\operatorname{method~} \mathrm{A})$ was 1,2-cyclopentylethane (3) formed in $27 \%$ yield, indicating that the cyclization of 5-hexenyl radical or an organometallic species is faster than dimerization. However, the other possible products, 1,11-dodecadiene (1) and the 7-cyclopentyl-1-heptene (2) were also observed in $3 \%$ and $14 \%$ yields, respectively. The use of a basic solution $\left(\mathrm{K}_{2} \mathrm{HPO}_{4}\right)$ and $\mathrm{CuI}$ led to a quite different selectivity, 1,11-dodecadiene (1) was the main product in $23 \%$ yield and compounds $\mathbf{2}$ and $\mathbf{3}$ were observed in $17 \%$ and $7 \%$, respectively (Table 4 ).

Table 4. Aqueous homocoupling of 6-iodo-hexene

\begin{tabular}{lllrrr}
\hline Entry & Solution & Metal/ catalyst & \multicolumn{3}{c}{ Products (\%) } \\
& & & (1) & (2) & (3) \\
\hline 1 & $\mathrm{NH}_{4} \mathrm{Cl}$ & $\mathrm{Zn} / \mathrm{CuCl}_{2}$ & 3 & 14 & 27 \\
2 & $\mathrm{~K}_{2} \mathrm{HPO}_{4}$ & $\mathrm{Zn} / \mathrm{CuI}$ & 23 & 17 & 7 \\
\hline
\end{tabular}

On the other hand, the homocoupling of iodomethylcyclopropane led only to one product, 1,7-octadiene (4), in up to $46 \%$ yield in all neutral or basic conditions tested (Table 5, entries 4 and 5), suggesting that the cyclopropylmethyl radical may have been formed followed by fast ring opening and a homocoupling reaction.

These observations led us to conclude that zinc mediated homocoupling reactions in aqueous media may go through radical intermediates and that rate constants for these coupling reactions should be much smaller than the rate constant of the cyclopropylmethyl ring opening and of the same order as the 5-hexenyl cyclization. 
Table 5. Aqueous homocoupling of cyclopropyl methyl iodide to 1,7-octadiene (4)

\begin{tabular}{llllr}
\hline Entry & Halide & Solution / Co-solvent a & Metal/ catalyst & $($ (4) $(\%)$ \\
\hline 1 & cyclo- $\mathrm{C}_{3} \mathrm{H}_{5} \mathrm{CH}_{2} \mathrm{Br}$ & $\mathrm{KOH} / \mathrm{CH}_{3} \mathrm{CN}$ & $\mathrm{Zn} / \mathrm{CuCl}_{2}$ & 20 \\
2 & cyclo- $\mathrm{C}_{3} \mathrm{H}_{5} \mathrm{CH}_{2} \mathrm{I}$ & $\mathrm{NH}_{4} \mathrm{Cl} / \mathrm{CH}_{3} \mathrm{CN}$ & $\mathrm{Zn} / \mathrm{CuCl}_{2}$ & 0 \\
3 & cyclo- $\mathrm{C}_{3} \mathrm{H}_{5} \mathrm{CH}_{2} \mathrm{I}$ & $\mathrm{NH}_{4} \mathrm{~F} / \mathrm{CH}_{3} \mathrm{CN}$ & $\mathrm{Zn} / \mathrm{CuCl}_{2}$ & 7 \\
4 & cyclo- $\mathrm{C}_{3} \mathrm{H}_{5} \mathrm{CH}_{2} \mathrm{I}$ & $\mathrm{K}_{2} \mathrm{HPO}_{4} / \mathrm{CH} \mathrm{CH}_{3}$ & $\mathrm{Zn} / \mathrm{CuI}$ & 40 \\
5 & cyclo- $\mathrm{C}_{3} \mathrm{H}_{5} \mathrm{CH}_{2} \mathrm{I}$ & $\mathrm{KOH} / \mathrm{CH}_{3} \mathrm{CN}$ & $\mathrm{Zn} / \mathrm{CuCl}_{2}$ & 46 \\
\hline
\end{tabular}

a $0.5 \mathrm{~mL}$ of co-solvent was used.

In an attempt to take advantage of the great difference in reactivity of structurally different halides, cross coupling reactions were performed with benzyl bromide, allyl bromide and t-butyl iodide using methods A, B and $\mathrm{C}$ as well other conditions. The best results were obtained with a aqueous $\mathrm{KOH}$ solution and $\mathrm{CuCl}_{2}$ as catalyst; however, the cross coupling products were observed only in moderate yields along with the homocoupling products (Table 6).

\section{Experimental}

All reagents were purchased from commercial suppliers and used without further purification.

${ }^{1} \mathrm{H}$ NMR spectra were recorded with a Varian Unity Plus 300 or a Varian EM 390 instrument.

GC/MS analyses were carried out on a Finnigan MAT GCQ-Ion Trap using a $30 \mathrm{~m}$ DB-5 capillary column, id $0.25 \mathrm{~mm}, 0.25 \mu \mathrm{m}$ film.

The Wurtz products are known coumpounds. The NMR data for homocoupling products of the crotyl, prenyl and cinnamyl halides are available in the literature. ${ }^{16}$

Iodomethylcyclopropane and 6-iodo-1-hexene were prepared from the bromides with $\mathrm{NaI}$ in acetonitrile.

All reactions were carried out at $30{ }^{\circ} \mathrm{C}$ for $2 \mathrm{~h}$ and no argon or nitrogen atmosphere was used.

The reaction yields were determined by $\mathrm{H}^{1} \mathrm{RMN}$ of the crude extract based upon the internal reference (anisole or cyclohexane) of known concentration.

\section{General procedure}

Method A. The organic halide $(1.0 \mathrm{mmol})$ and the catalyst $(10 \mathrm{mg}$ ) were stirred vigorously for $5 \mathrm{~min}$ in 2.0 $\mathrm{mL}$ of the aqueous solvent. The solvent used was: $1 \mathrm{~mol} \mathrm{~L}^{-1}$ $\mathrm{HCl}$ solution, saturated $\mathrm{NH}_{4} \mathrm{Cl}$ solution; saturated $\mathrm{CaCl}_{2}$ solution or $\mathrm{K}_{2} \mathrm{HPO}_{4}$ solution prepared with $1.5 \mathrm{~g}$ in $2.0 \mathrm{~mL}$ of water. Zinc dust ( $1.5 \mathrm{mmol})$ was added portionwise over a period of $10 \mathrm{~min}$. After stirring for $2 \mathrm{~h}$, the reaction mixture was acidified with $2 \mathrm{~mol} \mathrm{~L}^{-1} \mathrm{HCl}$ and extracted with $1.0 \mathrm{~mL}$ of $\mathrm{CCl}_{4}$ containing $0.050 \mathrm{mmol}$ of cyclohexane or $0.20 \mathrm{mmol}$ of anisole as internal quantitative reference. The extracts were analyzed directly by ${ }^{1} \mathrm{H}-\mathrm{NMR}$ and GC/ MS.

Method B. $\mathrm{K}_{2} \mathrm{HPO}_{4}(1.5 \mathrm{~g})$ or $\mathrm{KOH}(1.0 \mathrm{~g})$ was dissolved in $1.5 \mathrm{~mL}$ of water and $0.5 \mathrm{~mL}$ of co-solvent (benzene, dioxane or cyclohexane) was added. The organic halide $(1.0 \mathrm{mmol})$, the catalyst $\left(10 \mathrm{mg}\right.$ of $\mathrm{CuCl}_{2}$ or $0.5 \mathrm{mmol}$ of $\mathrm{CuI})$ and zinc dust $(1.5 \mathrm{mmol})$ were added to a vigorously stirred mixture of the salt solution and co-solvent. After 2 h, $1.0 \mathrm{~mL}$ of $2 \mathrm{~mol} \mathrm{~L}^{-1} \mathrm{HCl}$ was added and the mixture was extracted with $1.0 \mathrm{~mL}$ of $\mathrm{CCl}_{4}$ containing $0.050 \mathrm{mmol}$ of cyclohexane or $0.20 \mathrm{mmol}$ of anisole as internal quantitative reference. The extracts were analyzed as described above.

Method C. The organic halide (1.0 mmol), $\mathrm{AgNO}_{3}$ $(5 \mathrm{mg})$ and zinc dust $(1.5 \mathrm{mmol})$ were added to a vigorously

Table 6. Cross-coupling reactions mediated with zinc in aqueous media ${ }^{a}$

\begin{tabular}{|c|c|c|c|c|c|c|}
\hline \multirow[t]{2}{*}{ Entry } & \multirow[t]{2}{*}{$\mathrm{R}_{1} \mathrm{X}(\mathrm{mmol})$} & \multirow[t]{2}{*}{$\mathrm{R}_{2} \mathrm{X}(\mathrm{mmol})$} & \multirow[t]{2}{*}{ Conditions } & \multicolumn{3}{|c|}{ Products $(\%)^{\mathrm{b}}$} \\
\hline & & & & $\mathrm{R}_{1}-\mathrm{R}_{2}$ & $\mathrm{R}_{1}-\mathrm{R}_{1}$ & $\mathrm{R}_{2}-\mathrm{R}_{2}$ \\
\hline 1 & $\mathrm{CH}_{2}=\mathrm{CHCH}_{2} \mathrm{Br}(1.5)$ & $\left(\mathrm{CH}_{3}\right)_{3} \mathrm{CI}(0.5)$ & $\mathrm{KOH} / \mathrm{CuCl}_{2} / \mathrm{C}_{6} \mathrm{H}_{6}$ & 42 & 23 & 0 \\
\hline 2 & $\mathrm{PhCH}_{2} \mathrm{Br}(1.5)$ & $\left(\mathrm{CH}_{3}\right)_{3} \mathrm{CI}(0.5)$ & $\mathrm{KOH} / \mathrm{CuCl}_{2} / \mathrm{C}_{6} \mathrm{H}_{6}$ & 32 & 30 & 0 \\
\hline 3 & $\mathrm{CH}_{3} \mathrm{I}(1.5)$ & $\mathrm{PhCH}_{2} \mathrm{Br}(0.5)$ & $\mathrm{KOH} / \mathrm{CuCl}_{2}^{2} / \mathrm{C}_{6}^{\circ} \mathrm{H}_{6}^{0}$ & 22 & 0 & 53 \\
\hline 4 & $\mathrm{CH}_{2}=\mathrm{CHCH}_{2} \mathrm{Br}(1.5)$ & $\mathrm{PhCH}_{2}^{2} \mathrm{Br}(0.5)$ & $\mathrm{KOH} / \mathrm{CuCl}_{2}^{2} / \mathrm{C}_{6} \mathrm{H}_{6}^{0}$ & 35 & 34 & 12 \\
\hline
\end{tabular}

${ }^{\mathrm{a}}$ Typical procedure: the organic halide $(1.0 \mathrm{mmol}), \mathrm{CuCl}_{2}(10 \mathrm{mg})$ and zinc dust $(1.5 \mathrm{mmol})$ were added to a vigorously stirred mixture of $\mathrm{KOH}$ $(1.0 \mathrm{~g})$ in $1.5 \mathrm{~mL}$ of water and $0.5 \mathrm{~mL}$ of benzene as co-solvent. After $2 \mathrm{~h}, 1.0 \mathrm{~mL}$ of $2 \mathrm{~mol} \mathrm{~L}^{-1} \mathrm{HCl}$ was added and the mixture was extracted with $1.0 \mathrm{ml}$ of $\mathrm{CCl}_{4}$ containing the internal quantitative reference and analyzed as described before. ${ }^{\mathrm{b}}$ The cross coupling yield was obtained by $\mathrm{H}^{1} \mathrm{NMR}$ based on the limiting halide. 
stirred mixture of $\mathrm{KOH}(1.0 \mathrm{~g})$ in $1.5 \mathrm{~mL}$ of water and $0.5 \mathrm{~mL}$ of benzene as co-solvent. After $2 \mathrm{~h}, 1.0 \mathrm{~mL}$ of $2 \mathrm{~mol} \mathrm{~L}^{-1} \mathrm{HCl}$ was added and the mixture was extracted with $1.0 \mathrm{ml}$ of $\mathrm{CCl}_{4}$ containing the internal quantitative reference and analyzed as described before.

\section{Conclusion}

The zinc mediated aqueous coupling procedure provides an efficient and simple method for the homocoupling of benzylic and allylic bromides and primary alkyl iodides. Yields with secondary alkyl iodides are lower and tertiary halides give only trace amounts of the dimer. However, the latter can be used in cross coupling reactions with modest yields and selectivity.

The observed yields with benzylic and allylic halides were similar to those reported by $\mathrm{Chan}^{9}$ with $\mathrm{Mn}$ in aqueous medium. On the other hand, the yields obtained with benzyl bromide are higher than those obtained by Torii ${ }^{10}$ in organic media and the results with cinnamyl halides were comparable in yield and selectivity. It is worthwhile noticing that in both of the above cited methodologies, the reaction was carried out in an inert atmosphere and the reaction times ranged from 4 to $30 \mathrm{~h}$, while in the present case, the reaction is complete after $2 \mathrm{~h}$ and no inert atmosphere was used.

The unselective behavior in the cross-coupling reactions, high yields in the dimerization of neopentyl iodide, rearrangements of hexenyl and cyclopropyl methyl halides and the effect of copper and silver catalysts all point to a radical mechanism probably on the metal surface.

\section{Acknowledgments}

This work has been supported by the Brazilian agencies CNPq and FACEP.

\section{References}

1. Wurtz, A; Ann. Chem. Phys. 1855, 44, 275; Wurtz, A.; Ann. 1885, 96, 364.

2. Ullmann, F.; Ber. 1903, 36, 2389; Ullmann, F.; Spongel P.; Ber. 1905, 38, 2211; Fanta, P. E.; Chem Rev. 1964, 64, 613; Fanta, P. E.; Synthesis 1974, 9; Semmelhack, M. F.; J. Am. Chem. Soc. 1981, 103, 6460; Hassan, J.; Sevignon, M.; Gozzi, C.; Schulz, E.; Lemaire, M.; Chem. Rev. 2002, 102, 1359.
3. Konodo, Y.; Matsudaira, T.; Sato, J.; Murata N.; Sakamoto, T.; Angew. Chem. Int. Ed. Engl. 1996, 35, 736; Kang, S. K; Kim, T. H.; Pyun, S. J.; J. Chem. Soc., Perkin Trans. 1 1997, 797.

4. Fürstner, A.; Angew. Chem. Int. Ed. Engl. 1993, 32, 164.

5. Alonso, A. D.; Nájera, C.; Pacheco, M. C.; Org. Lett. 2000, 2 , 1823.

6. Zhang, S.; Zhang, D.; Liebeskind, L. S.; J. Org. Chem. 1997, 62, 2312.

7. Ranu, B.C.; Dutta, P.; Sarkar, A.; Tetrahedron Lett. 1998, 39, 9557.

8. Hassan, J.; Penalva, V.; Lavenot, L.; Gozzi, C.; Lemaire, M.; Tetrahedron 1998, 54, 13793.

9. Chan, T. H.; Ma, J.; Tetrahedron Lett. 1998, 39, 2499.

10. Torii, S.; Tanaka, H.; Yamashita, S.; Bull. Chem. Soc. Jpn., 1987, 60, 1951

11. Li, C. J.; Tetrahedron, 1996, 52, 5643; Lubineau, A.; Augé J.; Queneau, Y.; Synthesis 1994, 741; Bieber, L. W.; Silva, M. F.; Costa R. C.; Silva, L. O. S.; Tetrahedron Lett., 1998, 39, 3658.

12. Nosek, J.; Chem. Listy 1953, 47, 1236; Nosek, J.; Collect. Czech. Chem. Commun 1964, 29, 597.

13. Chan, T. H.; Li, C. J.; Organometallics 1991, 10, 2548.

14. Sasson, Y.; Mukhopadhyay, S.; Rothenberg, G.; Gitis, D.; Org. Lett. 2000, 2, 211.

15. Bieber, L. W.; Storch, E. C.; Malvestiti, I.; Silva, M. F.; Tetrahedron Lett. 1998, 39, 9393.

16. Clive, D. L. J.; Anderson, P. C.; Moss, N.; Singh, A.; J. Org. Chem., 1982, 47, 1641.

17. Bartleson, J. D.; Burk, R. E.; Lankelma, H. P.; J. Am. Chem. Soc., 1946, 68, 2513; Shortridge, R. W.; Craig, R. A.; Greenlee, K. W.; Derfer, J. M.; Boord, C. E.; J. Am. Chem. Soc. 1948, $70,946$.

18. Bieber, L. W.; Storch E. C.; Malvestiti, I.; J. Org. Chem. 1997, 62, 9061.

19. Garst, J. F.; Hart, P. W.; J. Chem. Soc., Chem.Comm. 1975, 215.

20. Applequist D. E.; Pfohl, W. F.; J. Org. Chem. 1978, 43, 867.

21. Ingold K. U.; Griller, D.; Acc. Chem. Res. 1980, 13, 317.

22. Nevill, S. M.; Pincock, J. A.; Can. J. Chem 1997, 75, 232.

23. Ingold, K. U.; Carlsson, D. J.; J. Am. Chem. Soc. 1968, 90, 7047.

24. Normant, J-F.; Meyer, C.; Marek, I.; Courtemanche, G.; Tetrahedron Lett. 1993, 34, 6053; Bailey, W. F.; Khanolkar, A. D.; Gavaskar, K.; Ovaska, T. V.; Rossi, K.; Thiel, Y.; Wiberg, K. B.; J. Am. Chem. Soc. 1991, 113, 5720.

Received: December 20, 2001

Published on the web: May 13, 2003 